DOI: https://doi.org/10.24127/ajpm.v10i3.3951

\title{
PENGEMBANGAN INSTRUMEN UJI KOMPETENSI UNTUK CALON GURU MATEMATIKA
}

\author{
Made Subowo $^{1 *}$, Akbar Nasrum ${ }^{2}$ \\ ${ }^{1 * 2}, 2$ Universitas Sembilanbelas November Kolaka, Kolaka, Indonesia \\ *Corresponding author. Address, 93511, Kolaka, Indonesia \\ E-mail: $\frac{\text { penelitianonline@gmail.com }}{{ }^{1 * 1}}$
}

Received 09 July 2021; Received in revised form 12 September 2021; Accepted 28 September 2021

\begin{abstract}
Abstrak
Tujuan dari penelitian ini adalah membuat suatu aplikasi yang dapat digunakan untuk menguji kompetensi calon guru matematika. Dengan aplikasi ini diharapkan dapat membantu dosen dalam menilai calon guru apakah pantas untuk diluluskan atau masih perlu ditempa. Untuk menghasilkan suatu aplikasi yang dapat diimplementasikan dibutuhkan empat tahapan yaitu: investigasi awal, tahap desain, tahap konstruksi/realisasi dan terakhir adalah evaluasi dan revisi. Tahap investigasi awal menentukan butir soal seperti apa yang ingin dimasukkan kedalam aplikasi. Pada tahap desain merancang tampilan soal dalam aplikasi seperti apa yang baik untuk para calon guru. Dalam tahap konstruksi/realisasi yaitu membuat aplikasi berdasarkan tahapan pertama dan kedua. Tahapan terakhir mengevaluasi dan merevisi kekurangan yang terdapat pada aplikasi yang telah dibuat. Hasil evaluasi materi dan evaluasi media dari dua Tim validasi menunjukkan angka dalam kategori baik. Hasil akhir diperoleh sebuah aplikasi ujian berbasis web yang telah teruji dan dinyatakan layak digunakan untuk menguji komptetensi calon guru matematika di Universitas Sembilanbelas November Kolaka.
\end{abstract}

Kata kunci: Evaluasi online; instrumen evaluasi; $i$-spring suite; pengembangan.

\begin{abstract}
The purpose of this study is to make an application that is useful for testing the competence of prospective mathematics teachers. With this application, it is hoped that it can help lecturers in assessing prospective teachers whether they are appropriate for graduation or still need to be forged. To produce an application that can be implemented, four stages are needed, namely: the initial investigation, the design stage, the construction/realization stage, and last is evaluation and revision. The initial investigation stage determines what items you want to include in the application. At the design stage, designing the appearance of questions in what kind of application is good for prospective teachers. In the construction/realization stage, namely making applications based on the first and second stages. The last stage is to evaluate and revise the shortcomings contained in the application that has been made. The results of the material evaluation and media evaluation from the two validation teams showed numbers in the good category. The final result is a web-based exam application that has been tested and declared suitable to be used to test the competence of prospective mathematics teachers at the University of Sembilanbelas November Kolaka.
\end{abstract}

Keywords: Development; evaluation instrument; $i$-spring suite; online evaluation.

This is an open access article under the Creative Commons Attribution 4.0 International License

\section{PENDAHULUAN}

Kurikulum pendidikan Indonesia dari tahun ke tahun mengalami perubahan. Perubahan ini merupakan salah satu langkah dalam memperbaiki kualitas pendidikan di Indonesia. Kulitas pendidikan yang baik tidak pernah lepas dari peran seorang guru. Gurulah yang pertama mengukir akan dibawa kemana generasi muda ini. Akankah dia menjadi generasi yang berkualitas dan bermartabat ataukah dia akan menjadi generasi 
perusak. Nasib generasi penerus bangsa berada ditangan guru. Oleh sebab itu, untuk memperbaiki nasib bangsa, hal pertama yang harus dilakukan adalah memperbaiki kualitas calon guru.

Ada banyak institusi pencetak calon guru di Indonesia seperti UPI, IKIP dan FKIP yang berada di dalam suatu Universitas tertentu. Setiap tahunnya institusi keguruan mencetak ratusan calon guru. Harapannya semua lulusan calon guru yang dihasilkan berkualitas. Kulitas dari calon guru yang dihasilkan tentu saja tidak lepas dari sistem pendidikan di satuan institusi tersebut. Salah satu instrumen yang dapat dijadikan sebagai alat untuk mengukur kualitas calon guru adalah instrument uji kompetensi. Jika calon guru lulus dalam ujian kompetensi, maka hal ini dapat dijadikan salah satu jaminan bahwa calon guru tersebut kompeten dalam bidangnya. Namun instrumen ujinya harus benar-benar valid dan bisa dipercaya (reliable).

Istrumen uji Kompetensi matematika bisa berbasis kertas ataupun berbasis komputer. Di era modern seperti sekarang instrument ujian atau alat evaluasi berbasis kertas sudah mulai ditinggalkan. Pasalnya instrument ujian berbasis komputer memiliki beberapa keunggulan dibandingkan evaluasi berbasis kertas (Nasrum, 2020). Bahkan saat ini ujian-ujian disuatu Lembaga Pendidikan sudah banyak yang berbasis android.

Evaluasi berbasis komputer ataupun berbasis android sudah banyak dipraktikkan oleh peneliti baik guru maupun dosen (Kusumaningrum et al., 2019). Mereka mengembangkan instrument evaluasi dengan tujuan dan metode yang berbeda-beda. Namun kebanyakan dari mereka mengembangkan alat evaluasi di sekolah karena ingin mengganti evaluasi berbasis konvensio- nal yang masih diterapkan di sekolahsekolah tempat mereka meneliti (Cahyanti et al., 2019; Candra Rolisca \& Achadiyah, 2014; Iqbal et al., 2018; Muhammad et al., 2018).

Ada juga peneliti yang mengembangkan alat evaluasi dengan tujuan untuk digunakan sebagai sarana ujian masuk ke sekolah, seperti di SMA Swasta Harapan I Medan (Dafitri, 2017). Sesuai hasil penelitiannya, alat yang dikembangkan layak digunakan untuk ujian masuk ke sekolah tersebut.

Metode yang digunakan dalam mengembangkan alat evaluasi pun berbeda. sehingga bentuk yang diperoleh juga tidak sama. Dalam instrumen evaluasi yang dikembangkan beberapa peneliti terdahulu hanya menyediakan butir soal tes untuk menguji kemampuan siswa. Beda halnya dengan penelitian yang dilakukan oleh (Muntoha et al., 2010) dan (Susilowati \& Ashari, 2013). Dalam alat evaluasi yang mereka buat ditambahkan menu untuk analisis butir soal serta analisis ketuntasan belajar. Jadi fungsinya tidak hanya sebagai alat evaluasi melainkan bisa menampilkan tingkat kesukaran soal, daya pembeda, validitas dan reliabilitas soal secara online sehingga bisa menjadi masukan bagi guru untuk selalu merevisi soal jika diperlukan.

Banyak software yang dapat digunakan untuk membuat alat evaluasi berbasis komputer baik offline maupun online. Ada software yang butuh keahlian khusus seperti penguasaan bahasa pemrograman. Adapula yang bisa langsung dipakai sekalipun tidak mengerti bahasa pemrograman, masih tetap bisa menciptakan suatu aplikasi.

Beberapa aplikasi yang tidak butuh bahasa pemrograman diantaranya adalah Wondershare Quiz Creator (WQC), ispring suite, quiziz, kahoot dan google form. WQC memiliki berbagai 
jenis pilihan jenis kuis dan luarannya sangat baik digunakan untuk aplikasi offline (Utin et al., 2021). Jika ingin membuat alat evaluasi berbasis online bisa menggunakan google form (Nofitasari \& Ahsani, 2020). Namun google form memiliki beberapa kekurangan terutama pada pengacakan soal dan timer dalam mengerjakan soal. Untuk instrumen lain seperti Kahoot bisa digunakan jika menginginkan kuis dalam bentuk permainan (Seftiani, 2019; Supriatini et al., 2020)

Contoh perangkat lunak pembuat aplikasi instrumen evaluasi yang butuh bahasa pemrograman adalah PHP. Biasanya perangkat lunak ini dipadukan dengan My SQL. Seperti yang dilakukan oleh (Sutopo, 2011). Hadi mengembangkan evaluasi pembelajaran berbasis multimedia dengan flash, PHP dan My SQL pada mata kuliah algoritma. Aplikasinya menggunakan bahasa pemrograman PHP dengan basis data My SQL, sementara Flash mendukung tampilan/interface yang dinamis.

Dalam penelitian ini akan dikembangkan insrumen evaluasi dengan tujuan yang berbeda dari semua penelitian terdahulu. Instrument yang akan dibuat bukan untuk ulangan harian atau ujian sekolah tingkat SMP atau SMA, bukan pula untuk ujian masuk ke sekolah-sekolah tertentu. Aplikasi ini dirancang dan diperuntukkan bagi calon guru matematika dan digunakan di tingkat Universitas. Komposisi soalnya juga bukan hanya beberapa materi di tingkat pendidikan tertentu melainkan gabungan soal dari tingkat SMP, SMA maupun soal dari perguruan tinggi itu sendiri. Cakupannya luas dan butir soalnya banyak. Boleh dikatakan bahwa ini merupakan bank soal SMP, SMA dan perguruan tinggi (Anggraini, 2013). Karena latar belakang pendidikan bukan bidang komputer, maka perangkat lunak yang digunakan adalah perangkat yang tidak butuh bahasa pemrograman.

Di Universitas Sembilanbelas November Kolaka khususnya program studi pendidikan matematika di bawah fakultas keguruan dan ilmu pendidikan belum memiliki instrumen khusus untuk uji kompetensi. Uji kompetensi dilaksanakan secara sederhana. Uji kompetensi diselipkan pada ujian skripsi. Mahasiswa cukup diberi beberapa soal secara lisan, jika semua soal terjawab maka mahasiswa dinyatakan lulus. Jika soal yang diberikan tidak terjawab, akan diberi soal lain dengan tingkat kesulitan lebih rendah. Kelemahan dari sistem seperti ini cenderung memberikan keputusan secara subjektif. Padahal keputusan seperti ini sangat mempengaruhi kualitas calon guru yang dihasilkan.

Untuk meningkatkan kualitas calon guru melalui uji kompetensi, perlu dikembangkan instrument uji kompetensi dalam bentuk aplikasi. Intrumen yang teruji, handal dan terpercaya dapat membantu para dosen menghasilkan calon guru yang berkualitas. Mahasiswa yang ingin lulus ujian tentu harus mempersiapkan diri sebaik mungkin karena harus berjuang sendiri tanpa bantuan dari pihak manapun. Hasil ujian yang diperoleh dari aplikasi ini murni dari kemampuan mahasiswa sendiri. Instrumen ini dapat memberi-kan hasil ujian yang objektif karena ketentuan lulus dan tidak lulus sudah diatur dalam sistem yang tidak dapat dimanipulasi.

Jadi tujuan khusus dalam penelitian ini adalah menciptakan sebuah aplikasi yang dapat digunakan untuk menguji kompetensi calon guru matematika. Aplikasi yang sudah teruji, handal dan terpercaya. Penelitian ini penting dilaksanakan agar kualitas calon guru matematika yang dihasilkan semakin meningkat. 


\section{METODE PENELITIAN}

Penelitian ini masuk dalam jenis penelitian pengembangan. Model yang digunakan yaitu model Plomp yang terdiri dari empat tahap (Nasrum, 2020). Tahap pertama merupakan investigasi awal. Pada tahap ini masalah didefinisikan. Sumber informasi dari tahap awal ini adalah beberapa dosen di program studi Pendidikan matematika Universitas Sembilanbelas November Kolaka termasuk kami sendiri. Tahap kedua merupakan tahap desain. Dalam tahap ini rencana pembuatan aplikasi mulai disusun untuk pemecahan masalah. Tahap ketiga adalah tahap realisasi/konstruksi yaitu tahap pembuatan aplikasi sesuai rencana yang telah dibuat. Tahap keempat adalah evaluasi dan revisi sebelum akhirnya produk diimplementasikan. Secara ringkas tahapanya dapat dilihat pada Gambar 1.

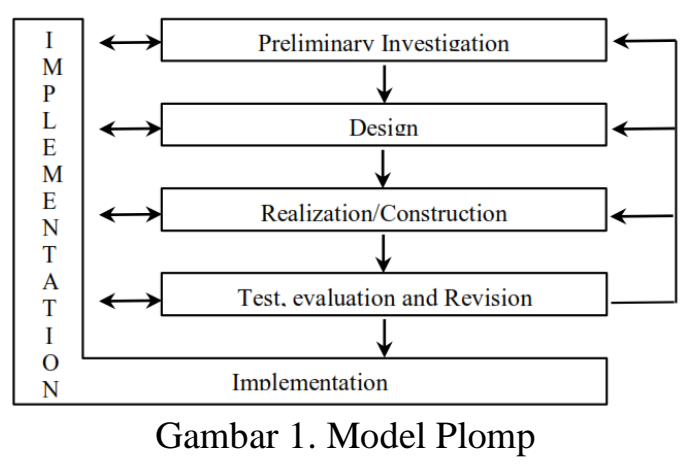

Instrumen penelitian yang digunakan ada beberapa macam. Pertama, instrumen khusus yang digunakan untuk membuat aplikasi soal yaitu berupa perangkat lunak. Dalam penelitian ini menggunakan Ispring Suite 9. Kedua, instrumen dalam validasi materi dan media (aplikasi soal) berupa angket atau lembar validasi. Lembar validasi ini digunakan untuk memvalidasi butirbutir soal yang akan dimasukkan ke dalam aplikasi ujian. Agar instrument ujian yang dihasilkan nanti valid, maka soal-soal yang dimasukkan kedalam aplikasi harus divalidasi, termasuk bentuk dan desain medianya. Angket validasi materi mengukur tiga aspek yaitu aspek materi, aspek konstruksi maupun aspek Bahasa. Sementara angket validasi media digunakan untuk mengukur empat aspek yaitu: aspek umum, penyajian, desain tampilan dan aksebilitas. Lembar validasi media diberikan setelah soal sudah dinyatakan layak oleh validator materi. Data yang diperoleh dari angket kemudian dianalisis dengan menghitung rerata jawaban berdasarkan skoring setiap jawaban dari validator (Widyoko, 2012).

Instrumen terakhir yang digunakan adalah prototipe yang dibuat. Prototipe instrumen uji kompetensi yang telah dibuat digunakan untuk mengukur taraf kesulitan dan daya beda dari soal (Fatimah \& Alfath, 2019).

Langkah-langkah yang dilakukan untuk membuat aplikasi uji kompetensi calon guru pendidikan matematika adalah sebagai berikut:

1. Membuat bank soal ujian mulai dari soal termudah sampai soal dengan tingkat kesulitan yang tinggi sesuai dengan kurikulum yang berlaku saat ini.

2. Verifikasi kebenaran soal dan jawabannya.

3. Membuat aplikasi menggunakan ispring suite 9 sesuai dengan desain yang dirancang.

4. Validasi butir soal yang telah dibuat oleh validator ahli materi.

5. Melakukan uji coba ke beberapa mahasiswa.

6. Validasi media oleh ahli media

7. Melakukan beberapa revisi sesuai masukan

8. Membuat prototipe final. 
DOI: https://doi.org/10.24127/ajpm.v10i3.3951

\section{HASIL DAN PEMBAHASAN}

\section{A. Fase Investigasi Awal}

Seperti yang telah dijelaskan pada bagian latar belakang sebelumnya bahwa tidak ada instrumen khusus yang digunakan untuk menguji kompetensi matematika calon guru yang akan dihasilkan. Pelaksanaannya hanya diselipkan pada ujian akhir Skripsi. Itupun hanya beberapa soal yang diberikan dan terkadang keputusan yang diambil bersifat subjektif. Oleh karena itu perlu disusun sebuah instrumen untuk memperbaiki kualitas calon guru yang dihasilkan.

Soal uji kompetensi yang dibuat terdiri dari dua tingkat yaitu tingkat mudah dan sedang. Cakupan materi untuk tingkat yang mudah adalah soalsoal SMP yang selanjutnya disebut tingkat I dan yang sedang adalah soalsoal SMA yang selanjutnya disebut tingkat II. Dua tingkat soal ini harus bisa dilewati oleh seorang calon guru matematika yang nantinya akan mengajar di sekolah.

Materi yang dimasukkan kedalam aplikasi disesuaikan dengan kisi-kisi UN nasional tahun 2019/2020 yang menggunakan kurikulum 2013. Dalam kisi-kisi tersebut, materi SMP dan SMA masing-masing dibagi dalam 4 kelompok materi. Tingkat I terdiri dari materi bilangan, Aljabar, Geometri dan Pengukuran serta Statistika dan Peluang. Sementara tingkat II terdiri dari materi Aljabar, Kalkulus, Geometri dan Trigonometri, Statistika dan peluang.

Ada beberapa materi yang tidak terdapat dalam kisi-kisi namun tetap dimasukkan dalam aplikasi karena materi ini adalah materi esensial. Materi tersebut adalah: logika matematika, teorema sisa, dimensi tiga, vektor, logaritma, lingkaran dan eksponen.

\section{B. Fase Desain}

Untuk membuat instumen uji kompetensi ada beberapa rencana yang telah disusun sebagai berikut:

1. Ditargetkan masing-masing tingkatan memiliki tidak kurang dari 800 soal sehingga peluang memperoleh soal yang sama sangat kecil manakala ada mahasiwa yang ujian bersamaan.

2. Soal terdiri dari dua jenis, ada pilihan ganda dan ada isian. Dalam sekali ujian terdiri dari 35 soal pilihan ganda dan 5 soal isian yang diambil secara acak dari bank soal yang tersedia.

3. Peserta harus menyelesaikan soal yang tampil sebelum melanjutkan ke soal berikutnya. Sengaja di desain seperti ini agar bisa meminimalisir kecurangan manakala pengawasan tidak ketat.

4. Waktu yang disediakan hanya 90 menit sehingga mahasiswa harus pintar-pintar mengatur waktu.

5. Ujian kompetensi bisa dilaksanakan menggunakan Laptop ataupun gadget/telepon pintar.

6. Ujian bersifat online, bagi yang lulus akan memperoleh Sertifikat yang dikirim ke email masingmasing.

\section{Fase Konstruksi/Realisasi}

Ini merupakan tahap terpanjang dari semua tahap yang ada. Dalam tahap ini dipilih perangkat lunak yang bisa merealisasikan apa yang direncanakan. Ada beberapa perangkat lunak yang bisa digunakan dalam membuat suatu alat evaluasi/ujian tapi tidak semuanya bisa digunakan sesuai dengan rencana. Sebagai contoh Wondershare Quiz Creator (WQC) dapat memenuhi rencana ke 2, 3 dan 4. Namun untuk rencana 5 dan 6 tidak ada jaminan bisa dilaksanakan. Luaran dari WQC 
memiliki banyak kelemahan pada saat dionlinekan apalagi saat mengerjakan menggunakan gadget/HP Android. Ada pula software yang sangat mendukung pelaksanaan ujian online seperti google form namun kita tidak bisa memilih bebeberapa soal dari bank soal yang tersedia. Olehnya itu dipilih software Ispring Suite 9 yang dapat memenuhi apa yang sudah direncanakan.

Setelah memilih software yang akan digunakan maka langkah selanjutnya adalah mengumpulkan soalsoal baik dari internet maupun bukubuku. Mengelompokkan soal permateri dan memilih soa-soal yang mempunyai karakteristik yang sama. Karakteristik yang sama meberikan info awal tentang tingkat kesulitan pada suatu kelompok soal. Soal tersebut disusun kembali sembari memverifikasi kebenaran redaksi soal dan jawabannya. Dalam pelaksanaanya ada beberapa soal yang redaksi kalimatnya kurang tepat sehingga harus diganti. Tidak sedikit juga ditemukan soal-soal yang pilihan jawabannya kurang tepat. Semua itu harus diperbaiki atau harus diganti.

Setelah semua soal sudah diverifikasi, selanjutnya dilakukan penginputan soal ke software. Proses ini juga memakan waktu yang cukup lama karena tidak semua soal bisa dicopy paste. Hanya soal yang berbentuk tulisan biasa yang bisa dicopy. Tulisan matematika harus diketik ulang dan jika ada gambar harus diinput satu persatu.

Setelah penginputan soal selesai dilanjutkan dengan pengaturan tampilan soal. Sesuai dengan rencana diambil 35 soal pilihan ganda dan 5 soal isian dari bank soal yang sudah tersedia. Waktu diatur hanya 90 menit dan kemunculan soal serta jawabannya diacak.

Setelah pengaturan soal selesai maka prototipe I siap dibuat. Prototipe I adalah intrumen Uji Kompetensi yang sudah jadi namun belum divalidasi. Contoh tampilan dari media yang dibuat dapat dilihat pada Gambar 2.
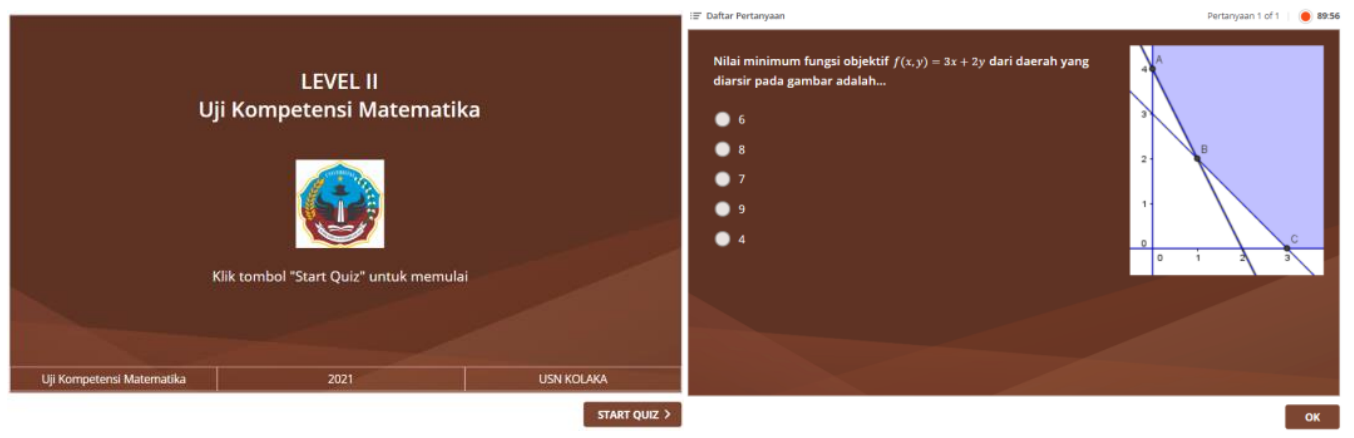

Gambar 2. Tampilan muka dan salah satu tampilan soal berbasis web.

Prototipe I ini kemudian divalidasi oleh validator materi dan validator media. Validator materi adalah dosen dari program studi pendidikan matematika yaitu Bapak Halidin, S.Pd., M.PMat dan Bapak Arbain, S.Pd., M.Si. Validator media dipilih dari dosen yang mempunyai latar belakang penelitian tentang media evaluasi atau media pembelajaran. Validator I adalah Bapak Farman, S.Pd., M.Pd dari program studi
Pendidikan Matematika dan validator kedua adalah Bapak Kadaruddin, S.Pd., M.Pd dari program studi Pendidikan Bahasa Inggris.

Validator melakukan tes berulangulang untuk melihat kesesuaian kurikulum, substansi soal dan aspek kemampuan calon guru. Hasil yang diberikan menunjukkan bahwa dari sisi materi, instrumen ini sudah baik. 
DOI: https://doi.org/10.24127/ajpm.v10i3.3951

Adapun hasil dari validasi materi dapat dilihat pada Tabel 1.

Tabel 1. Hasil validasi materi

\begin{tabular}{llcc}
\hline \multirow{2}{*}{ No } & \multirow{2}{*}{ Aspek } & \multicolumn{2}{c}{ Tim Validator } \\
\cline { 3 - 4 } & & V1 & V2 \\
\hline 1 & Materi & 4 & 4 \\
2 & Konstruksi & 4,25 & 3,875 \\
3 & Bahasa & 4 & 4 \\
\hline & Rata-rata & 4,08 & 3,96 \\
\hline
\end{tabular}

Berdasarkan hasil analisa data yang ada pada Tabel 1, rata-rata nilai yang diberikan oleh dua validator masing-masing berada diatas 3,5 (skala 5). Ini menunjukkan bahwa soal-soal yang disediakan dalam alat evaluasi sudah masuk dalam kategori baik. Artinya soal-soal tersebut dinyatakan valid sebagai instrumen evaluasi.

Walaupun demikian masih ada beberapa yang harus diperbaiki seperti sedikit kesalahan penulisan, beberapa gambar kurang jelas tapi masih bisa dibaca, sebaiknya diganti oleh validator. Hal seperti ini jika tidak diperbaiki tentu akan berpengaruh pada hasil validasi media dalam aspek penyajian oleh karena itu prototipe 1 dibenahi sebelum diserahkan ke validator media. Setelah diperbaiki kemudian diberi nama prototipe 2. Selanjutnya hasil validasi oleh validator media dapat dilihat pada Tabel 2.

Tabel 2. Hasil validasi media

\begin{tabular}{llcc}
\hline \multirow{2}{*}{ No } & \multirow{2}{*}{ Aspek } & \multicolumn{2}{c}{ Tim Validator } \\
\cline { 3 - 4 } & & V1 & V2 \\
\hline \multirow{2}{*}{ Umum } & 3,5 & 3,5 \\
2 & Penyajian & 3,5 & 3,5 \\
3 & Tampilan & 3,5 & 3,5 \\
4 & Aksesibilitas & 4 & 3,5 \\
\hline & Rata-rata & 3,63 & 3,5 \\
\hline
\end{tabular}

Hasil yang diperoleh dari dua validator menunjukkan angka rerata diatas 3,5. Angka ini menunjukan bahwa penilaian media sebagai alat evaluasi masuk dalam kategori baik (Widyoko, 2012).

Selanjutnya prototipe ini diujicobakan kepada 40 mahasiwa matematika yang diambil secara acak. Hasil ujian kemudian dianalisis untuk mengukur tingkat kesukaran dan daya beda dari butir soal yang dibuat. Adapun hasil dari pengukuran tingkat kesukaran, daya pembeda, dan reliabilitas disajikan pada Tabel 3.

Tabel 3. Hasil ukur taraf kesukaran, daya beda dan uji reliabilitas

\begin{tabular}{lccc}
\hline & \multicolumn{2}{c}{ Butir Soal } & \multirow{2}{*}{ Ket } \\
\cline { 2 - 3 } & TK I & TK II & \\
\hline IK & Sedang & Sedang & Layak \\
DB $<\mathbf{0}$ & $1,8,10$, & $7,9,11$, & \\
& 17,26 & 24,26 & Hapus \\
$\boldsymbol{r}$ & 0,362 & 0,347 & Reliabel
\end{tabular}

Berdasarkan analisis data hasil uji diperoleh nilai Indeks kesukaran untuk semua butir soal baik tingkat I maupun tingkat II berada dalam rentang 0,25 dan 0,75. Ini berarti bahwa indeks kesukaran butir soal adalah sedang dan layak digunakan untuk soal ujian (Fatimah \& Alfath, 2019).

Untuk daya beda butir soal, ada 5 soal yang daya bedanya negatif, baik tingkat I maupun tingkat II. Semuanya adalah soal pilihan ganda. Kelompok butir soal ini dihapus dari sistem sehingga soal yang ditampilkan dalam prototipe akhir hanya 35 soal.

Untuk kriteria tingkat kepercayaan soal digunakan metode tes paralel. Dari hasil uji diperoleh koefisien korelasi seperti pada tabel 3. Masingmasing koefisien korelasi dari dua tipe soal tersebut lebih besar dari koefisien korelasi tabel $(0,312)$ sehingga instrumen ujian yang dibuat reliabel.

Setelah melewati proses validasi, menentukan tingkat kesukaran dan daya 
beda soal, uji reliabilitas dan lulus uji kelayakan media maka dilanjutkan dengan produksi prototipe final yang kemudian ditempatkan pada sebuah website sebagai wadah yang mudah diakses untuk Uji Kompetensi. Instrumen Uji kompetensi Final yang sudah dibuat dapat dilihat pada link https://sites.google.com/view/akbarnasr um/uji-kompetensi.

Dari beberapa proses yang telah dilalui mulai dari fase investigasi awal hingga realisasi rencana, diperoleh sebuah instrumen uji kompetensi matematika berbasis web sebagai sebuah temuan utama dalam penelitian ini. Dikatakan berbasis web karena ditempatkan pada sebuat website. Keunggulan dari instrument berbasis web adalah dapat diakses baik menggunakan laptop maupun menggunakan smartphone sehingga tidak mempersulit mahasiswa yang tidak memiliki laptop.

Selain menghasilkan instrumen uji kompetensi matematika, sebagai akibat dari pelaksanaan penelitian ini juga diperoleh bank soal yang dapat dimodifikasi sesuai dengan keinginan pengguna. Bank soal yang terkumpul dalam pembuatan instrument uji kompetensi dapat digunakan untuk intsrumen evaluasi akhir pada mata pelajaran matematika untuk siswa SMP atau siswa SMA. Bukan hanya itu, melalui bank soal yang tersedia, dapat disusun instrument evaluasi matematika untuk kenaikan kelas, bahkan dapat diatur sebagai alat evaluasi pada pertengahan semester atau bahkan ulangan harian. Instrumen yang akan dibuat tinggal disesuaikan dengan materi yang akan dimasukkan.

Beberapa kekurangan dari produk yang telah dibuat antara lain: (1) Web Hosting yang digunakan masih menggunakan web hosting gratisan.
Web Hosting gratis banyak diminati oleh orang-orang yang ingin belajar tentang website sehingga banyaknya pengguna dapat menyebabkan akses terhadap web tidak lancar. Akibatnya untuk mengakses kuis kadang-kadang mengalami kendala. Kadang cepat, kadang lambat tergantung dari banyaknya pengguna. (2) Soal yang dimasukkan dalam instrumen uji kompetensi belum memuat soal-soal tingkat perguruan tinggi, kecuali beberapa materi tentang Kalkulus sehingga ukuran kompetensi mahasiswa lulusan hanya sebatas matematika SMP dan SMA saja. (3) Nilai ujian belum bisa dikonversi dalam bentuk file excel sehingga jika peserta ujian cukup banyak, akan cukup merepotkan untuk merekap datanya satu persatu. Hal ini dikarenakan perangkat lunak Ispring yang digunakan adalah perangkat lunak yang tidak berbayar.

Disamping kekurangan yang disebutkan di atas, ada beberapa kelebihan dari produk yang sudah dibuat. Pertama, instrument uji ini dapat mengukur kompetensi mahasiswa dalam bidang matematika secara komprehensif lebih baik daripada sistem ujian yang dilakukan hingga saat ini. Pasalnya ujian kompetensi mahasiswa saat ini hanya menguji beberapa materi dasar saja. Kedua, dari sisi penilaian mahasiswa, instrument ini sangat objektif. Tidak seperti sistem ujian saat ini yang kadangkala cenderung masih bersifat subjektif. Boleh jadi ada mahasiswa yang belum bisa dikatakan kompeten, namun karena sesuatu dan lain hal, mahasiswa tersebut bisa diluluskan. Jika menggunakan instrument yang sudah dibuat, maka hal-hal seperti itu tidak akan terjadi karena nilai kelulusan secara otomatis ditentukan oleh sistem. 
Dari sisi media, instrumen uji atau instrumen evaluasi yang dibuat menggunakan perangkat lunak Ispring suite selalu mendapat penilaian yang baik dari validator media. Hal ini karena tampilan soal yang disajikan memang baik, fasilitas soal yang tersedia juga lengkap dan fitur navigasi yang dapat diatur sesuai yang diinginkan.

Dalam penelitian ini, instrumen uji yang dibuat mendapat kategori baik dari validator media. Hal ini juga sejalan dengan penelitian-penelitian terdahulu seperti (Cahyanti et al., 2019; Rovita et al., 2020). Bahkan dalam penelitian mereka penilaian dari ahli media mendapat kriteria yang sangat layak. Padahal perangkat lunak yang digunakan oleh (Cahyanti et al., 2019) masih versi 8.0. Sementara yang digunakan dalam penelitian ini adalah versi 9.0 yang jauh lebih baik daripada versi 8 , terutama dalam hal pengetikan matematika.

Hasil penelitian ini diharapkan dapat berguna di program studi Pendidikan matematika Universitas Sembilanbelas November Kolaka dan menjadi solusi untuk menyaring caloncalon guru matematika profesional.

\section{KESIMPULAN DAN SARAN}

Melalui proses yang cukup panjang akhirnya tercipta suatu instrumen uji kompetensi untuk calon guru matematika di Universitas Sembilanbelas November Kolaka. Instrumen ini sudah melalui beberapa tahap uji coba, verifikasi dan validasi sehingga minim dari kekeliruan. Selain instrumen uji kompetensi matematika yang telah dibuat, melalui master bank soal yang sudah ada dapat dikembangkan instrumen lain seperti instrumen latihan soal menghadapi SBMPTN, latihan soal menghadapi ujian untuk SMP maupun SMA.

\section{UCAPAN TERIMAKASIH}

Kami mengucapkan terimakasih yang sebesar-besarnya kepada DRPM Kementerian Pendidikan, kebudayaan, riset dan teknologi yang telah membiayai penelitian ini melalui skema Penelitian Dosen Pemula pendanaan tahun 2021.

\section{DAFTAR PUSTAKA}

Anggraini, S. dan D. (2013). Pengembangan Bank Soal Dan Pembahasan Ujian Nasional Berbasis Multimedia Pembelajaran Interaktif Dengan Macromedia Authorware 7.0. Jurnal Cakrawala Pendidikan, 3, 394-408. https://doi.org/10.21831/cp.v0i3.113 8

Cahyanti, A. D., Farida, F., \& Rakhmawati, R. (2019). Pengembangan Alat Evaluasi Berupa Tes Online/Offline Matematika dengan Ispring Suite 8 . Indonesian Journal of Science and Mathematics Education, 2(3), 363371.

https://doi.org/10.24042/ijsme.v2i3. 4362

Candra Rolisca, R. U., \& Achadiyah, B. N. (2014). Pengembangan Media Evaluasi Pembelajaran Dalam Bentuk Online Berbasis E-Learning Menggunakan Software Wondershare Quiz Creator Dalam Mata Pelajaran Akuntansi Sma Brawijaya Smart School (Bss). Jurnal Pendidikan Akuntansi Indonesia, 12(2). https://doi.org/10.21831/jpai.v12i2.2 706

Dafitri, H. (2017). Pemanfaatan Wondershare Quiz Creator Dalam Tes Berbasis Komputer. QUERY: Jurnal Sistem Informasi, 01(01), 818.

Fatimah, L. U., \& Alfath, K. (2019). Analisis Kesukaran Soal, Daya Pembeda dan fungsi Distraktor. 
DOI: https://doi.org/10.24127/ajpm.v10i3.3951

Jurnal Komunikasi Dan Pendidikan Islam, 8(2), 37-64.

Iqbal, W. M. G., Fadhilah, R., \& Hardiati, D. (2018). Pengembangan Alat Evaluasi Berbasis Wondershare Quiz Creator Pada Materi Koloid Kelas XI di SMA Koperasi Pontianak. Ar-Razi Jurnal Ilmiah, 6(1), 11-15.

Kusumaningrum, Y., Handayani, T., \& Wakhidah, N. (2019). Pengembangan Aplikasi Mobile Untuk Try Out Ujian Nasional Matematika Pada Siswa Smk Kelas Xii. Jurnal Pengembangan Rekayasa Dan Teknologi, 15(1), 33. https://doi.org/10.26623/jprt.v15i1.1 487

Muhammad, A., Mappeasse, M. Y., \& Arfandi, A. (2018). Pengembangan Instrumen Evaluasi Pembelajaran Pada Mata Pelajaran Sistem Komputer Berbasis E-Xam Caraka Di SMK Negeri 1 Bantaeng. Jurnal Pendidikan, 1(2), 26-29.

Muntoha, M., Akhlis, I., \& Subali, B. (2010). Pengembangan Sistem Evaluasi Pembelajaran Berbasis Web (Web Based Learning Assessment System). Pertemuan Ilmiah XXIV, April, 195-199.

Nasrum, A. (2020). Pengembangan Instrumen Evaluasi Pemahaman Konsep Kalkulus Berbasis Komputer. Histogram: Jurnal Pendidikan Matematika, 4(1), 7992.

https://doi.org/http://dx.doi.org/10.3 1100/histogram.v4i1.540

Nofitasari, \& Ahsani, E. L. F. (2020). Pelaksanaan Evaluasi Pembelajaran Berbasis Google Form Selama Masa Pandemi Pada Peserta Didik SD/MI. Terampil: Jurnal Pendidikan Dan Pembelajaran Dasar, 7(2), 107-118. Rovita, C. A., Zawawi, I., \& Huda, S. (2020). Pengembangan Alat Evaluasi Pembelajaran Matematika Berbasis Two Tier Multiple Choice
Menggunakan Ispring Suite 9 Postulat: Jurnal Inovasi Pendidikan Matematika Salah satu bagian terpenting dalam suatu pembelajaran ada. Jurnal Inovasi Pendidikan Matematika, 1, 150-164.

Seftiani, I. (2019). Alat Evaluasi Pembelajaran Interaktif Kahoot pada Mata Pelajaran Bahasa Indonesia di Era Revolusi Industri 4 . 0. Prosiding Seminar Nasional Bulan Bahasa (Semiba) 2019, 284-291.

Supriatini, Refson, \& Mustofa. (2020). Pengembangan Alat Evaluasi Menggunakan Kahoot pada Pembelajaran Bahasa Indonesia untuk Siswa kelas VII. Bindo Sastra, 4(1), 48-62. https://jurnal.umpalembang.ac.id/bisastra/article/vie w/2206

Susilowati, E. B., \& Ashari, A. (2013). Pengembangan Sistem Evaluasi Kegiatan Belajar Mengajar Berbasis Web Studi Kasus : di SMA Negeri 1 Surakarta. IJCCS (Indonesian Journal of Computing and Cybernetics Systems), 7(2), 199208.

https://doi.org/10.22146/ijccs.3360

Sutopo, H. (2011). PENGEMBANGAN EVALUASI PEMBELAJARAN BERBASIS MULTIMEDIA DENGAN FLASH, PHP, DAN MySQL. Jurnal Informatika, 11(1), 79-85.

https://doi.org/10.9744/informatika.1 1.1.1-7

Utin, E., Duda, H. J., \& Julung, H. (2021). Pengembangan Alat Evaluasi Menggunakan Komputer Berbasis Wondershare Quiz Creator. Journal Education and Technology, $1,1-10$.

Widyoko, E. P. (2012). Teknik Penyususnan Instrumen Penelitian. Pustaka Pelajar. 